\title{
FACTORS AFFECTING STUDENT VIEWS OF AFGHANISTAN AND THAILAND ABOUT ISLAMIC EDUCATION CURRICULUM CONTENT IN PONDOK PESANTREN LUHUR WAHID HASYIM SEMARANG
}

\author{
Nur Setyaningrum \\ Universitas Nahdlatul Ulama \\ nurse_afganisme@yahoo.com
}

\begin{abstract}
This paper describes the analysis of the factors that led to their different views and Thailand Afghan students at the University of Wahid Hasyim about the content of curriculum in Pondok Pesantren Luhur Wahid Hasyim (PPLWH) Semarang. The background of this work, first, the students of Afghanistan to counter the unwillingness and the opt-out on non-formal education in PPLWH. One reason for the problem because the curriculum content presented too dense. Second, on the other hand there is uniqueness, students demonstrated Thailand. Namely, the existence of conditions of Thai students learning environment that is unstable and a variety of issues as well as negative fact, it strengthens their reaction to learning through pesantren education offered at the University of Wahid Hasyim. The second view of the type of student on Indonesian pesantren curriculum content is very important, one of them in Pondok Wahid Hasyim. This is because the University of Wahid Hasyim is the University of Nahdlatul 'Ulama in Indonesia which implemented a system of boarding schools. The other reason for the two types of these students have different cultural backgrounds (the Middle East and Southeast Asia) but still in one ideology, Islam.
\end{abstract}

Key words: Islamic boarding school, curriculum content.

\begin{abstract}
Abstrak
Makalah ini menjelaskan analisis faktor-faktor yang menyebabkan pandangan mereka yang berbeda dan mahasiswa Afghanistan Thailand di Universitas Wahid Hasyim tentang isi kurikulum di Pondok Pesantren Luhur Wahid Hasyim (PPLWH) Semarang. Latar belakang pekerjaan ini, pertama, para siswa Afghanistan untuk melawan ketidaksediaan dan ketidakikutsertaan pada pendidikan non-formal di PPLWH. Salah satu alasan masalah karena isi kurikulum yang disajikan terlalu padat. Kedua, di sisi lain ada keunikan, siswa menunjukkan Thailand. Yakni, adanya kondisi lingkungan belajar siswa Thailand yang tidak stabil dan beragam masalah serta fakta negatif, justru memperkuat reaksi mereka terhadap pembelajaran melalui pendidikan pesantren yang ditawarkan di Universitas Wahid Hasyim. Pandangan kedua tentang jenis siswa pada konten kurikulum pesantren Indonesia sangat penting, salah satunya di Pondok Wahid Hasyim. Ini karena Universitas Wahid Hasyim adalah Universitas Nahdlatul 'Ulama di Indonesia yang menerapkan sistem pesantren. Alasan lain untuk dua jenis siswa ini memiliki latar belakang budaya yang berbeda (Timur Tengah dan Asia Tenggara) tetapi masih dalam satu ideologi, Islam.
\end{abstract}

Kata kunci: pesantren, konten kurikulum.

\section{Introduction}

Pesantren world within the framework of Hussein Nasr is the traditional Islamic world, meaning the world who inherited and sustaining the Islamic 
tradition of scholars for the future to the past. ${ }^{1}$ Pesantren are now able to survive not only because of its ability adjustment and readjustment, but also because of the character esistensinya. ${ }^{2}$ In view Nurcholish Madjid, not only as an institution that is synonymous with the meaning of Islam but also "implies authenticity Indonesia (indigenous).

Pesantren grow and develop from the experience of the sociological community. That is, schools have relevance to the community environment. This fact not only did we see the background of the establishment of schools, but also in the maintenance of the existence of pesantren. ${ }^{3}$ In addition, pesantren have not only provide religious education services, but also the social and economic guidance for the community. So with this context, pesantren kiai has an important role as cultural brokers "brokers culture" (cultural broker) in view of Clifford Geertz. ${ }^{4}$

This adult community expectations towards schools actually getting stronger. Pesantren is expected to not only carry out its traditional functions and became the center of social and economic empowerment of the people, but also capable of running a social role, such as social rehabilitation center. Unfortunately, the popularity of Islamic education at boarding school did not

1 Azyumardi Azra, Pendidikan Islam: Tradisi dan Modernisasi di Tengah Tantangan Milenium III, (Jakarta: Kencana Prenasa Media Group, 2012), p.129

2 Pesantren has a different culture to the surrounding culture, distinctive culture. Some researchers refer to it as part of the culture (sub culture) that have idiosyncratic nature, pooling pattern (Sulthon \& Khusnuridlo, 2006: 6). This can be seen from the way of teaching at the school is unique. Often called the method bandongan and shove. (1) Method bandongan or collective services (collective learning process), namely Sang Kiai read classical religious manuscripts in Arabic (yellow book), while the students noted. (2) Method sorogan or individual services (individual learning process), which is a method of teaching where students read a book while listening kijaji or religious teacher while correcting and evaluating readings.

${ }^{3}$ In terminological (Hamzah) as cited by Karel A. Steenbrink (1985: 20) pesantren seen from the form and the system was originally from India. After the entry and spread Islam in Java, the system was taken over by Islam. However, unlike stated by Mahmud Jonah that individual education used in schools and education that begins with the Arabic language, it can be found in Baghdad when it became the center and capital of the Islamic region. The issue of the origin of the boarding school can not be completed, prior to the issue of the historical advent of Islam in Indonesia itself completely. Regarding the term cottage itself is derived from the Arabic, funduk (guesthouse / lodging for people traveling). But it is too simple, if we assume that the terms are not labeled Arab is not from Islam (Steenbrink (1985: 22).

4There are a number of important elements in the system of boarding schools. (1) Elements Kiai, he is the leader, the supreme teacher and often the owners of boarding. He is regarded as a model for the life of Muslims everyday. He also became a place for the contest on religious matters, social, and psychological. (2) Elements students, the students in a boarding school. Pupils are divided into two, students and students Mukim bats. Pupils mukim are those who come from far away and stay in boarding schools. While students bats, are those that come from the area around the school and do not stay in boarding schools. (3) Place of residence (dormitory), it's usually not much of a place to stay clerics. (4) mosque, a place of prayer and worship and a place of learning. (5) pengajians classical Islamic literature, commonly called yellow book. There is a high level of uniformity in the selection of the books contained in all traditional schools. Especially books homage to the Shafi'i madhhab in law and Ash'ari theology. There are only a small number of schools that build recitation tradition yellow book itself, such as Pondok Gontor Ponorogo, and Pondok Pesantren Modern Exactly Bangil Muhammadiyah Pacitan, Lamongan. This difference is usually oriented reform ideas of Islam (Mughni, 2001: 298-301). 
have a very big appeal in view of the Afghan students. This is in contrast with the view that Thai students at the University of Wahid Hasyim. They have a great interest in learning at boarding school. Almost the majority of Afghan students in the University of Wahid Hasyim have a view that the content of the curriculum in Pondok Pesantren Luhur Wahid Hasyim presented too dense. In addition there are the views of others will be content in the boarding school's curriculum. This paper is an analysis of the factors that affect both types of student's view on the content of Islamic education curriculum in Pondok Pesantren Luhur Wahid Hasyim.

\section{Content Curriculum Islamic Education at Boarding School}

Society is always constantly changing and evolving, so many emerging new life issues that need to be solved. So it will affect the curriculum content, therefore the content of the curriculum should be developed.

The development would not be separated from the context of the correlation with the perception and the basic meaning of the curriculum content it self.

Hymen defining curriculum content as quoted Wirawan et al. as:

Science (such as facts, information, principles, definition), skills and processes (such as reading, writing, arithmetic, dancing, critical thinking, oral communication, and writing) and values (such as the concept of good things, bad, right and wrong, beautiful and ugly).

Meanwhile, John Dewey, for example, assesses there is a material difference to science.

For experts who distinguish mean that the materials or content are records of knowledge (such as graphs, symbols, tape, etc.), whereas science is seen as the result of comprehension and understanding of the records as a result of their interaction with individual experience.

From these definitions, it can be concluded that the content of the curriculum are records about the knowledge, skills and processes, as well as values. All three of these components has its own meaning, 1) component of knowledge is something comprehension and understanding of the results of those records as a result of its interaction with the individual experiences (such as facts, information, principles, definitions). 2) Skills and processes (such as reading, writing, arithmetic, dancing, critical thinking, oral communication, and writing). 3) Component values (such as the concept of good things, bad, right and wrong, beautiful and ugly).

Definition as mentioned above is true, but the discussion of this aspect of the curriculum content includes not only the amount of material in the written curriculum content, but also regarding the existing curriculum content on hidden currilulum. Among them was the structural aspect and the cultural aspect. Structural aspects include the division of classes, a variety of activities outside of learning, facilities are provided, including textbooks and various programs that 
are taught. While the cultural aspect includes norms school, hard work ethic, roles and responsibilities, social relations between individuals and between groups, rituals and worship celebration, cooperation, tolerance, and that teachers' expectations on his student. Thus, the discussion of aspects of the curriculum content is not only contained in the written content alone.

Further related Islamic education. Islamic education curriculum according to Mohammed bin Sahlun as presented by Al-Kailani in writing Heri Gunawan, especially in the teaching of the Koran should be about'i'rab Koran, syakal, spelling, how to write a good, read, and tahsin reading the Koran. While the teachers should also teach them to pray, perform ablution and pray. In addition, according to Syamsuddin, he also advocated studying the sciences in addition to Al-Quran on the grounds that the other sciences was essentially derived from the Koran.

Similar to Muhammad bin Sahlun, next is the Islamic education curriculum according to Muhammad bin Husain Al-Teach. According pemahamannnya, teaching the basic principles of the Koran is teaching the Koran, al-Sunnah, atsaratsar the companions of the Prophet, and tabi'in after friends, and the maxim of the Muslim imam. He said that this is an attempt to stay away from people who like to do heretic.

Slightly different from the Ali bin Muhammad Al-Qabisiy as cited by Gunawan (1014: 303) states that the Islamic education curriculum is divided into two. First, it is imperative (ijbary) that Al-Quran al-Karim, fiqh, faraid, write khat, 'i'rab al-Quran al-Karim, tahsin Qu'ran, and some other basic sciences. Second, is optional (ikhtiyari) ie numerology, syaer, stories of Arab society, the history of Islam, science and Arabic Nahwu complete.

Furthermore dikemukanan by Al-Haris Al-Muhabisi about the curriculum of Islamic education, he suggested that the learning process began with the teaching of monotheism (belief). Khalid continued human relationship with her, the lessons of human existence and properties, followed by tha'at and surrounding nature (nature wara ', piety and muhasabah to yourself), and the last study about everything that God commanded him (abiding in the field religious and social).

Thought other education curriculum, according to Muhammad Al-Ghazali. He theorized that the educational curriculum is determined from the purpose of education itself. More details, he mentioned that the science is divided into two. First, discuss the issues Ijbariyah (liabilities) or Fard 'Ain. Cakupannnya about the science of tawhid, the science tahdib al-Nas (human education), and the science of al-Sharia (jurisprudence Allah). Second, deals Ikhtiariyah or Fardhu Kifayah, the scope of medical science, mathematics, skills, political, nafwu, interpretation and jurisprudence. Based on such a division, the division of the educational curriculum according to Al-Ghazali formulated in two tendencies. First, the 
curriculum of religion and mysticism. Second, the curriculum pragmatic tendency that could have an impact on the life of this world and the Hereafter.

\section{Students view of Afghanistan and Thailand on Curriculum Content in Pesantren}

\section{Afghan student views}

View of Afghan students at the University of Wahid Hasyim about the content curriculum of Islamic education in boarding school that the basic teachings of Fiqh, Quran, Hadith, Morals, Tarikh Islam as in Afghanistan. However, the level of assessment of the curriculum content is not better than in Afghanistan. Due geographically in their general view that Afghanistan have close relations with Arab countries and symbolically (based fonts used in Farsi) has many similarities with Arabic letters Hij'iyyah.

In addition, the application of Islamic law which is good in Afghanistan (especially in the case of this particular restrictions on interaction between men and women in everyday life with more stringent environmental and awake) is considered as a sign of the practices and principles of curriculum content in the country better. However, on the one hand about the concept of science, and the values of the content curriculum of Islamic education in Indonesia more democratic rated and liked by them. The reason, in the practical implementation and daily interactions, the Indonesian people to respect differences, as well as providing the freedom for women to receive education in accordance with the interests or talents. It also includes an assessment of the curriculum content in schools is considered good because it directs students to perform religious attitudes, distinguishing good and bad as a creature of Allah.

Based on some research results indicate that students' view of Afghanistan to the content of the curriculum in Pondok Pesantren Luhur Wahid Hasyim fairly good. They believe that boarding schools are considered part of the Indonesian educational institution that is able to teach his students a religious education. About the content of the curriculum in these institutions, they assess: (1) Related component of knowledge on the content of the curriculum, according to their charge in a pretty good curriculum, of which there is the teaching of the Quran and other religious matters, about the good and the bad. However, according to the material taught in the Pondok Pesantren Luhur Wahid Hasyim, was considered too much.

(2) Section skills and processes within the content of the curriculum at the boarding school student Wahid Hasyim in Afghanistan in view of the University of Wahid Hasyim is believed that the learning process is too "full time". If the pupil / student must complete a morning and an afternoon of learning at school or college, then go back to boarding school when they will be presented with a variety of studies. Another view, curriculum content related chapters of this 
process that the practice of prayer held in a slightly different Indonesian boarding school with their school of thought.

Furthermore, (3) related to the view component values in the curriculum content in Pondok Pesantren Luhur Wahid Hasyim, Afghan students considered that the concepts contained within the content quite well. According to them the content of curriculum in schools geared to run instances of religion, to distinguish good and bad as a creature of God. In addition, the purpose of content was directed at Islam desired expectations.

\section{Student views Thailand}

View of Thai students at the University of Wahid Hasyim about the content of the curriculum of Islamic education in boarding schools sublime Wahid Hasyim said content is taught in accordance with their experiences in Thailand, their study of the book of yellow and Jawawi (study fiqh Malay term Thailand) if at boarding school, and patterned mahdzab Sunni Shafi. Furthermore, studies related components of the process and skills, they perceive that the process needs to take into account the time which is not too dense. However, habituation patterns of worship, the process of reading, writing, communicating in content, pretty good especially in boarding school. Similarly, the value of the component chapters. The views they mention that the Islamic education curriculum content Indonesia, khusnya at Pondok Pesantren Luhur Wahid Hasyim, was able to achieve the expected goals and good value.

The results of the investigation, as data presented shows a view of Thai students to the curriculum content as follows: (1) Related component of knowledge in the curriculum, particularly education in boarding schools who rate their view there is pretty good and there are very good judging. According to the knowledge component in the yellow book also examined the content and Jawawi (Malay term study of Figh Thailand). In addition, the content of the material was more on the style of Mahdzab Shafi'i as they profess. However, on the one hand, they perceive that the curriculum content related knowledge component, is still lacking in learning resources. Source study assessed only limited to the classics.

Furthermore, (2) in the discussion of curriculum content and process skills chapter Pondok Pesantren Luhur Wahid Hasyim bit saturating. Where not all the material on the content of the curriculum studied were able to apply them in real life. Almost similar to the Afghan student, wishes to have the content of the curriculum in execution (process, including consideration of the time) is proportional to the understanding and implementation practices. However, their view of the habit, worship skills, and processes that exist in the schools considered to be very good, as an example for their routine presence and prayers. 
Finally, (3) chapters curriculum content component values, they see that the content of the curriculum in Pondok Pesantren Luhur Wahid Hasyim able to achieve the expected goals.

Despite having good grades in their views about the content of the curriculum in Pondok Pesantren Luhur Wahid Hasyim, but actually in the process of receiving the curriculum content is not delivered properly. The perfection of the process of absorption of this content can only be is passed with the support of a range of methods and strategies in both the implementation of the curriculum.

\section{Factors that influence student views Afghanistan and Thailand}

Factor in the view of the selection process are:

\section{Psychological Factors}

Based on psychological factors, the student needs more Afghan students interested in studying in the lecture bench. Included also in religion, they are more interested in studying religion through the lecture bench. This is different from the situation needs Thai students at the University of Wahid Hasyim. In addition to the psychological background of learning needs in the lecture bench, Thai students are also interested in learning to Islamization in institutions provided, be it formal or informal. Even the reaction to the religious needs of those embodied in the weekly or monthly discussions along with other Thai students around Semarang and outside Semarang. This requirement is based on the belief that religion is tarbiyah that started small and wherever located.

Obtained a description of these factors, that in the process of organizing this view will experience the difference. Input to the content of the curriculum in the educational curriculum Pondok Pesantren Luhur student Wahid Hasyim in Thailand will be greater than the input Afghanistan curriculum content to students. The reason, no other upper psychological needs are different, so the form of reciprocal any different. However, how much percentage of the effect on the formation of view, the need for additional research on the psychology of this type of element.

\section{Background factors}

Based on the factors that influence the process of organizing, the background has the most influence. In view of this study, the research object, the Afghan students have different backgrounds with Thai students. Both geographically different, and different in mahdzab adopted. Afghan student background are those of in the Middle East region which is predominantly $99 \%$ are Muslim. Bermahdzab populated Sunni Hanafi 80\% -85\%, whereas 15\% - $20 \%$ bermahdzab Shiite Muslims. Likewise types Afghan students at the University of Wahid Hasyim, most of them Sunni Hanafi bermahdzab, and the other part bermahdzab Ja'fari Shi'i Muslims. 
If we compare the condition of community demographics Thailand 95\% Hindus and the rest are Muslim, Christian, and Hindu Coincidentally, Thai students at the University of Wahid Hasyim, all Muslims from the southern Thailand provinces of Pattani, Yala, and Narathiwat.

Seeing the geographic and demographic background of the two types of these students would give effect to the organization of the views on the content of the curriculum of Islamic education in Indonesia. Such differences, namely the Afghan students who have a background of everyday life with religious conditions in which Islam is very influential in culture conditions during his stay in Afghanistan, and Thai students who previously lived in an engaging environment between the Buddhist community and Islam.

On background relationships with the background, when juxtaposed to the environmental conditions of Islam in Indonesia, the two sides have different views. From the research, the Afghan students have the view that Islamic education in Afghanistan is better than Islamic education in Indonesia. While the Thai students have the view that Islamic education in Indonesia better than in Thailand. It is indirectly have an influence in shaping the views and their reactions to the content curriculum of Islamic education in Indonesia.

\section{Experience Factor}

Based on research from the standpoint of the experience factor, the Afghan student University of Wahid Hasyim in the country more to get content / curriculum materials similar to those mahdzab (Hanafi) in school. While they were bermahdzab Ja'fari gained more curriculum content of teaching parents and formal education in Afghanistan mosque.

This experience gives a special meaning if they have to study Islamic education with curriculum content that is more inclined to the Sunni Shafi'i as it existed at the Foundation University of Wahid Hasyim both in institutions and in institutions nonformalnya university in boarding school.

In contrast, if resting on the results of research on Thai students at the University of Wahid Hasyim. Altogether, such as followers of Sunni Muslim students mahdzab Shafi. Included in the learning experience of religion in Thailand country, learning content creed, Nahwi, Sharf, history, Al-Quran, Arabic, Figh even had already become a regular review them during in Thailand. However, certainly in learning Islamic education in Indonesia, they are certainly more interested in the content curriculum in accordance with mahdzab Sunni Shafi.

\section{Personality Factors}

This personality factors influence the process of organizing the view. From the research, students classified as type extroverted Afghanistan, where dislike of something, spurring them to immediately to the people around him. It is actually 
easier for researchers to find the extent to which their views on the content curriculum of Islamic education in Indonesia. But according to researchers, the impact of negative attitudes priceless extrovert, able to influence and sugestion also for those around him. If such attitudes are not met with critical power and selectivity, it will result in mistaken view. In contrast to Thai students, they better have a personality similar to the Malays. Including adab adalam everyday life, their personality matching with the environment in Indonesia, making adjustments with the neighborhood more easily than students in Afghanistan.

The diversity of the nature of the two types of these students also affect the ease of them to socialize. Including the introduction of Islamic education curriculum content, where things are familiar will be mnarik attention. Thai students are easier to adapt practice and learning process in the Islamic education curriculum content, one reason is certainly because of their religious practices similar to those that exist in Indonesia.

\section{Popular Belief}

Based on the research results, the general belief was formed by students of Afghanistan against Islamic education in Indonesia considered that the educational curriculum content Afghanistan better than in Afghanistan. It is in the underlying because of their belief that feel closer to the region and Islamic countries and cultures that exist in the country more obedient to the laws of Islam than in Indonesia. However, that belief is not entirely believed to have static meaning. In a sense, the reaction is raised to the curriculum content was regarded amereka tune with the needs and enough to attract their attention. For instance, some of which follow the teachings of Al-Qurann bin-Nadzar in Pondok Pesantren Luhur Wahid Hasyim and Quran recitation. For some other teaching related to direct curriculum content, teaching haditz, figh, there has been no immediate reaction from them.

Quite different to Thai students at the University of Wahid Hasyim, research data shows that attitudes and their general beliefs on curriculum content in Pondok Pesantren Wahid Hasyim Luhur high enough. In their belief, the general public has the notion that Islamic education, including curriculum content is considered good because the majority of Indonesia's population is Muslim society.

\section{External Factors}

These external factors of which consists of things that are associated with the intensity, contrast, movement, repetition, even intimacy, as well as things that are new. Seeing this definition, this factor is more dzahir or can be seen with the senses. These factors can be external environment, or anything related to Islamic education curriculum content directly. For example, on the method, the atmosphere of delivery / practice of curriculum content, infrastructure, media. 
In this case, based on the results of the study showed that for Afghan students at the University of Wahid Hasyim respond to any shortcomings in the delivery method on the content of Islamic education curriculum in schools. Their disinterest in the teaching and learning process is too crowded. In addition, according to their lifestyle education in boarding schools ranging from dwelling too simple.

However, different views with Thai students. Rate them on education and the style of life in the boarding school was mediocre. Cause, if seen from their experience factor, almost the majority of schools have studied in Thailand before.

Differing views on these external factors also caused differences in the process of organizing the view. Their disinterest in the learning process, learning media, and several other external factors cause the absence of reciprocal relationship is formed. It is based on the theory that, in view of stimulation or symptoms, subjects tend to focus on the symptoms that arise and stand. While the other symptoms that are in the background.

Seeing these factors, it is clear that there are some external factors on the process of Islamic education in Indonesia is less a positive impact. Factors that comes from learning methods, infrastructure, and media themselves are directly able to stimulate interest in Islamic education in general and curriculum content in particular. Therefore, the best effort to realize a positive outlook and a positive reaction also requires hard work led to the existence of these factors make it more attractive so that later able to influence the views.

\section{Conclusions and Recommendations}

Factors that more influence in Afghanistan and Thailand student views about the content of the curriculum in Pondok Pesantren Luhur Wahid Hasyim more influenced by internal factors. One of these interests and backgrounds, different schools of thought.

For bearers institute Islamic education curriculum. We realize it or not, the difference to the school has become an isolated case among participants intern students. Even ignorance of this sect distinction allows the commission of intolerance among the adherents. Thus, the need for content comparison schools as outlined in the curriculum of Islamic education institutions, especially in schools. (1) can be included as a separate chapter on Islamic Education in Public Schools (2) Loaded in the chapter of its own content on the study of Islamic Fiqh School/Madrasah. Thus, learners can understand this difference. However, since the content curriculum of Islamic education in Indonesia is more skewed in one particular branch of Islam, then it is good comparison to the school curriculum content is placed in high school and not on school grounds. (3) Content knowledge of the differences can be put on the schools of Islamic education courses can be included in a separate credits or the study of Islamic jurisprudence. (4) As for the public college or society in general, the content ratio 
/ difference this sect is better presented in the form of education that is integrated with other contents. For example, could be included in the study seminar to Islamization or other meetings.

For the government or institutions of Islamic education in Indonesia. The necessity form distinctive technique in delivering forms of Islamic education in Indonesia. Models can be done in nonformal education. With other techniques integrative. Although the Indonesian government introduced the country or from the Central Board of Nahdlatul Ulama (NU) is a state not of the adherents of the same school of Muslim-majority Indonesia, it actually contains its own risks. But on the other hand also provides advantages both in diplomacy to introduce Islam in Indonesia to global regions. Either will work up or not, but at least the steps in research will give effect to the Indonesian Islamic education in the world of eyewear. The most important in view of the relationship between both inter content inii curriculum of Islamic education in Indonesia or view the relationship with other content, is communication.

\section{References}

Ahmad. Baso. (2013). Pesantren Studies, Jakarta: Pustaka Afid.

Ahmad. Suaedy. (2012). Dinamika Minoritas Muslim Mencari Jalan Damai: Peran Civil Society Muslim di Thailand Selatan \& Filipina Selatan, Jakarta: Puslitbang Lektur dan Khazanah Keagamaan Badan Litbang dan Diklat Kementerian Agama RI dan CISEAS-The Wahid Institute.

Alex. Sobur. (2009). Psikologi Umum dalam Lintasan Sejarah, cetakan II, Bandung: Pustaka Setia.

Azyumardi. Azra, (2012) Pendidikan Islam: Tradisi dan Modernisasi di Tengah Tantangan Milenium III, Jakarta: Kencana Prenasa Media Group.

Karel A. Steenbrink. (1986). Pesantren Madrasah Sekolah: Pendidikan Islam dalam Kurun Modern. Jakarta: LP3ES.

Maimun Aqsa. Lubis. Et all. (2011) "The Perception in Method in Teaching and Learning Islamic Education", International Journal of Education Information Technologies, Vol.5., Malaysia: Facultyof Education, Universiti Kebangsaan Malaysia.

Mumtaz. Akhter. Tanveer Iqbal, \& Mubashra Khalid. (2010). "Islamic Educational Approach to Environment Protection: A Strategic Approach for Secure and Peaceful World", International Journal of Business and Social Science, Vol. 1 No. 3 December 2010. USA: Centre for Promoting Ideas, downloadable date September 19, 2015, from www.ijbssnet.com.

Pia. Karlsson \& Amir Mansory. (2007). An Afghan Dilemma: Education, Gender and Globalisation in an Islamic Context, Swedia: Institute of International Education, Department of Education Stockholm University.

Sulthon \& Khusnuridlo. (2006). Manajemen Pondok Pesantren dalam Perspektif Global. Yogyakarta: LaksBang PRESSindo.

Syafiq A. Mughni. (2001) Nilai-Nilai Islam: Perumusan Ajaran dan Upaya Aktualisasi. Yogyakarta: Pustaka Pelajar.

Wina Sanjaya. Ibrahim. dkk. (2011). Kurikulum dan Pembelajaran, Bandung: Rajawali Pers. 
Yasmen, Samina, 2008, Understanding Muslim Identities: From Perceived Relative Exclusion to Inclusion, (E-Book), Australia: Centre for Muslim State and Societies, University of Western, downloadable date, March 72015. 